\title{
Kelimpahan dan Biomassa Ikan Karang Famili Scaridae pada Ekosistem Terumbu Karang di Perairan Pulau Kembar, Karimunjawa, Jepara
}

\author{
Fran Ciputra Tambunan*, Munasik, Agus Trianto \\ Departemen IImu Kelautan, Fakultas Perikanan dan IImu Kelautan, Universitas Diponegoro \\ JI. Prof.H.Soedarto S.H, Tembalang,Semarang, Jawa Tengah 50275 Indonesia \\ ${ }^{*}$ Corresponding author, e-mail: franciputratambunan@students.undip.ac.id
}

\begin{abstract}
ABSTRAK : Ikan kakatua merupakan salah satu ikan karang yang dapat membantu kehidupan pada ekosistem terumbu karang. Scaridae mengumpulkan berbagai spesies ganggang dengan cara memakan algae pendek yang menutupi substrat karang sehingga dapat mempengaruhi pertumbuhan terumbu karang. Sebaran Scaridae sangat ditentukan oleh kondisi dan variasi habitat terumbu karang. Penelitian ini bertujuan untuk mengetahui kelimpahan dan biomassa dari ikan Famili Scaridae. Penelitian dilaksanakan pada bulan Oktober 2018 di Perairan Pulau Kembar, Karimunjawa, Jepara. Pengambilan data ikan karang menggunakan metode UVC dan data substrat terumbu karang diambil menggunakan metode LIT sepanjang 100 meter sejajar garis pantai dengan pengamatan pada dua kedalaman yaitu $3 \mathrm{~m}$ dan $10 \mathrm{~m}$. Berdasarkan hasil penelitian, didapatkan 11.459 individu yang termasuk dalam 49 spesies ikan karang yang berasal dari 14 famili. Ikan karang dari Famili Scaridae ditemukan sebanyak 1059 individu yang termasuk dalam 4 spesies ikan karang yang berasal dari 2 genus. Nilai kelimpahan ikan karang dari Famili Scaridae berkisar antara 48 hingga 204 ind $/ 500 \mathrm{~m}^{2}$, kelimpahan terendah berada pada stasiun 1 dan tertinggi berada di stasiun 3. Nilai biomassa ikan karang dari Famili Scaridae berkisar antara 219,7-2491,7 kg/ha, biomassa terendah berada pada stasiun 1 dan tertinggi berada di stasiun 3 . Berdasarkan hasil penelitian dapat disimpulkan bahawa Pengaruh tutupan karang keras hidup sangat berpengaruh terhadap kelimpahan dan biomassa ikan karang dari Famili Scaridae.
\end{abstract}

Kata Kunci : Ikan Kakaktua; Biomassa Scaridae; Terumbu Karang; Pulau Kembar

\section{Abundance and Biomass of Scaridae Family of Coral Fish in the Coral Reef Ecosystem in the Waters of the Twin Islands, Karimunjawa, Jepara}

\begin{abstract}
Parrot fish is one of the reef fish that can help life on the coral reef ecosystem. Scaridae collect various species of algae by eating short algae that cover the coral substrate so that it can affect the growth of coral reefs. Scaridae distribution is highly determined by the condition and variety of coral reef habitats. This study aims to examine the abundance and biomass of Scaridae Family fish. The study was conducted in October 2018 in the waters of the Kembar Islands, Karimunjawa, Jepara. Retrieval of reef fish data using UVC method and coral reef substrate data were taken using the LIT method along 100 meters along the coastline with observations at two depths in $3 \mathrm{~m}$ and 10. Based on the results, 11,459 individuals were included in 49 species of reef fish originating from 14 families. Coral fish from the Family Scaridae were found as many as 1059 individuals included in 4 species of reef fish originating from 2 genera. The value of coral fish abundance from the Scaridae Family ranges from 48 to 204 ind / 500m2, the lowest abundance is at station 1 and the highest is at station 3. The reef fish biomass value of the Scaridae Family ranges from $219.7-2491.7 \mathrm{~kg} / \mathrm{ha}$, biomass the lowest is at station 1 and the highest is at station 3. Based on the results of the study it can be concluded that the effect of live hard coral cover is very influential on the abundance and biomass of reef fish from the Scaridae Family.
\end{abstract}

Keywords : Parrot fish; Scaridae Biomass; Coral Reef; Kembar Islands 


\section{PENDAHULUAN}

Kepulauan Karimunjawa terletak di sebelah Timur Laut kota Semarang tepatnya pada posisi $5^{\circ} 40^{\prime}-5^{\circ} 57^{\prime}$ LS dan $110^{\circ} 4^{\prime}-110^{\circ} 40^{\prime}$ BT. Kep. Karimunjawa termasuk dalam wilayah administrasi Kecamatan Karimunjawa, Kabupaten Jepara, yang terdiri dari tiga Desa yaitu Desa Karimunjawa, Kemujan dan Parang. Taman Nasional Karimunjawa dengan gugusan pulau sebanyak 22 buah memiliki luas wilayah daratan dan perairan seluas 111.625 hektar. Dari 22 pulau tersebut terdapat empat pulau berpenghuni yaitu P. Karimunjawa, P. Kemujan, P. Parang dan P. Nyamuk (Umardiono, 2011). Pulau Kembar terletak di Barat Pulau Karimunjawa, Kabupaten Jepara, Karimun Jawa dan mempunyai luas hektar 6,7 Ha. Pulau Kembar berada di dekat pulau Parang dan pulau Kumbang serta berhadapan langsung dengan laut lepas (perairan Laut Jawa). Pulau Kembar memiliki banyak sekali potensi sumberdaya hayati dan keanekaragaman yang tinggi serta berada pada zonasi pemanfaatan oleh Balai Taman Nasional Karimunjawa. Pulau Kembar masuk dalam zonasi pemanfaatan, dikarenakan hal tersebut diperlukan adanya survei terhadap keadaan Ekosistem yang bervariasi pada pulau Kembar seperti hutan mangrove, ikan karang dan terumbu karang. Pulau Kembar merupakan pulau di Karimun Jawa dengan potensi sumberdaya ikan karang yang sangat besar, dengan Densitas $0,64 \mathrm{ekor} / \mathrm{m}^{2}$, Kelimpahan 80,0242 ton, Potensi 40,0121 ton/th, dan MSY 16,0048 ton/th (Yusuf, 2013)

Ikan karang merupakan salah satu komunitas pada ekosistem terumbu karang yang berperan penting dalam aliran energi dan menjaga kestabilan ekosistem (Nybakken, 1992). Ikan karang juga menggunakan bentuk-bentuk pertumbuhan terumbu karang untuk perlindungan dan pertahanan diri dari predator (Hixon, 1991). Bentuk pertumbuhan karang bermacam-macam seperti bercabang, masif, lembaran, dan lainnya digunakan oleh berbagai jenis ikan untuk bersembunyi. Oleh karena itu, keberadaan ikan karang di ekosistem terumbu karang tergantung pada tingkat kesehatan terumbu karang.

Ikan kakatua merupakan salah satu jenis ikan herbivora yang utama di ekosistem terumbu karang (Sale, 1991). Ikan kakatua terdiri dari berbagai jenis, karena memiliki jumlah genus yang cukup banyak yaitu 7 genera dengan genus terbanyak adalah Scarus. Ikan kakatua hidup di sekitar terumbu karang dan biasanya ditemukan juga pada perairan dangkal dengan kedalaman sampai 30 meter. Cara membedakan jenis ikan kakatua yang paling mudah adalah dengan melihat komposisi warna, karena ikan kakatua memiliki variasi warna yang beraneka ragam pada tubuhnya (Sale, 1991).

Ikan kakatua (Scaridae) hidup di perairan tropis dan subtropis. Ikan berukuran kecil (juvenile) banyak ditemukan hidup di daerah padang lamun, sedangkan ikan berukuran dewasa hidup di daerah terumbu karang (Adrim, 2008). Ikan kakatua merupakan salah satu ikan karang yang dapat membantu kehidupan pada ekosistem terumbu karang dengan cara memakan alga epilithik pendek yang menutupi substrat karang sehingga secara tidak langsung dapat mempengaruhi pertumbuhan terumbu karang tersebut (Adrim, 2008). Penurunan kondisi terumbu karang baik oleh faktor alam ataupun dengan faktor manusia akan memengaruhi distribusi dan sebaran ikan karang dalam suatu area terumbu

Tujuan penelitian untuk mengetahui kelimpahan dan biomassa dari ikan Famili Scaridae yang berada di Pulau Kembar, Karimunjawa, Jepara. Biomassa ikan karang merupakan nilai estimasi dari hubungan panjang dan berat ikan karang, dengan mengukur panjang total ikan karang dari masing - masing spesies ikan karang yang terdapat di area terumbu karang (metode estimasi).

\section{MATERI DAN METODE}

Materi yang digunakan pada penelitian ini adalah ikan karang famili Scaridae dan tutupan terumbu karang. Titik lokasi penelitian terdiri atas 4 stasiun yaitu Stasiun 1 berada di bagian timur, Stasiun 2 berada di bagian utara, Stasiun 3 berada di bagian barat dan Stasiun 4 yang berada di bagian selatan. Pengamatan dilakukan pada setiap stasiun di 2 kedalaman yang berbeda yaitu kedalaman 3-5 meter dan 8 - 10 meter di Pulau Kembar. Pengambilan data ikan karang menggunakan metode sensus visual (Visual Census Method) menurut English et al., (1997) yang secara teknis dilakukan dengan metode transek sabuk (belt transect) (Gambar 1). Transek yang 
digunakan adalah transek garis sepanjang 100 meter dengan jarak pengamatan $2,5 \mathrm{~m}$ ke arah kiri dan $2,5 \mathrm{~m}$ ke arah kanan sehingga luas keseluruhan wilayah yang diamati adalah $500 \mathrm{~m}^{2}$.

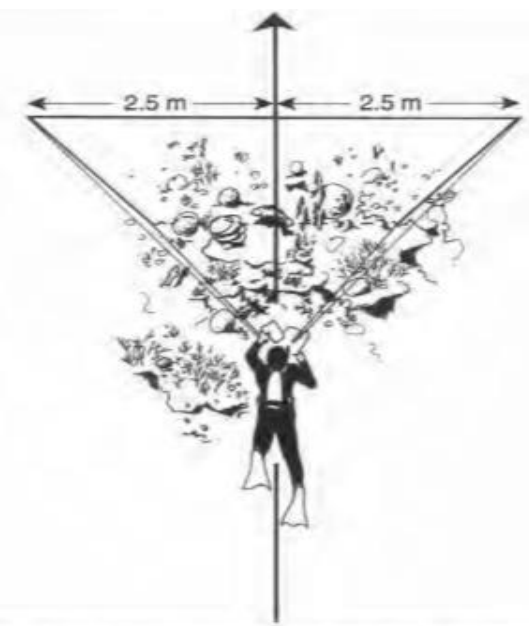

Gambar 1. Metode Pengamatan Visual Sensus Untuk Ikan Karang (Sumber: English et al., 1997).

\section{Metode Identifikasi Ikan Karang}

Identifikasi ikan karang dilakukan secara langsung di dalam air dengan memperhatikan ciri khusus atau tanda yang ditemukan pada ikan karang baik pada tubuh maupun ekornya sehingga diperoleh spesies ikan karang. Dalam identifiksi ikan karang tingkat genus maupun spesies, hal yang perlu diperhatikan adalah ciri - ciri khusus atau tanda yang ditemukan, baik pada tubuh maupun ekornya. Antara lain : garis tegak lurus verikal (Bar); garis melintang (Band); garis tegak lurus horizontal (Stripe); titik - titik kecil yang tidak teratur (Speckles); bulatan atau lingkaran (Spot); dan tanda bercak (Blotch) (Allen et al., 2003).

\section{Pengamatan Data Persentase Tutupan Terumbu Karang}

Pengamatan biota karang sebagai komponen utama penyusun ekosistem terumbu karang dan berbagai organisme bentik lainnya dilakukan dengan metode line intercept transect (LIT). Metode ini digunakan untuk mengestimasi penutupan karang hidup ataupun mati. Posisi transek ditentukan dengan menggunakan Global Positioning System (GPS). Pada titik pengamatan transek garis (roll meter) dibentangkan sepanjang 100 meter, yang diletakkan sejajar garis pantai dengan mengikuti kontur kedalaman. Penamatan dilakukan untuk dua tingkat kedalaman, yaitu 3 dan 10 meter. Pengamatan biota pengisi habitat dasar menurut English et al., (1997) didasarkan pada bentuk pertumbuhan (lifeform).

\section{Persentase Tutupan Terumbu Karang}

Besar persentase tutupan karang mati, karang hidup, dan jenis lifeform lainnya dihitung dengan rumus menurut English et al. (1997):

$$
C=\frac{a}{A} \times 100
$$

Keterangan $: C=$ Persentase penutipan karang keras; $A=$ Panjang transek $/$ life form $k e-1 ; A=$ Panjang total transek

Gomez dan Yap (1988), mengkategorikan kondisi terumbu karang berdasarkan hasil persentase tutupan substrat yaitu : Excellent (Sangat baik) $=75-100 \%$; Good (Baik) = 50-74,9\%; Fair $($ Cukup $)=25-49,9 \% ;$ Poor $($ Buruk $)=0-24,9 \%$

\section{Kelimpahan Ikan Karang Scaridae}

Analisis kelimpahan ikan karang yang berada di terumbu karang dihitung dengan menggunakan rumus menurut English et al. (1997) sebagai berikut: 


$$
N=\frac{n i}{A}
$$

Keterangan : $\mathrm{N}=$ Kelimpahan ikan (individu $\left./ \mathrm{m}^{2}\right) ; \mathrm{A}=$ Luas area yang diamati $\left(\mathrm{m}^{2}\right) ; \mathrm{ni}=$ Jumlah individu spesies ke-i

\section{Biomassa Ikan Karang Scaridae}

Menurut Kulbicki et al., (2005) penghitungan dan estimasi ukuran ikan karang akan dikonversi ke nilai rata - rata (mean) (+standart error) dan kepadatan biomassa di setiap lokasi untuk famili dari spesies ikan kakak tua (scaridae). Estimasi ukuran akan dikonversi ke estimasi biomassa dengan hubungan panjang-berat yang diketahui setiap spesies dan dihitung nilai rata rata (mean) biomassa dari hasil pengamatan lapangan, dengan menggunakan rumus :

$$
W=a L^{b}
$$

Keterangan : $W=$ berat ikan dalam $(\mathrm{g}) ; \mathrm{L}=$ Panjang total $(\mathrm{TL})$ ikan dalam $(\mathrm{cm}) ;$ a dan $\mathrm{b}=$ nilai konstan yang dihitung untuk setiap spesies.

Parameter biomassa ( $a$ dan $b$ ) setiap ikan, dicari rata - ratanya dan digunakan untuk menghitung nilai biomassa per famili dengan total luasan pengamatan, dengan menggunakan rumus :

$$
\frac{\text { biomassa per unit sampling }(\mathrm{kg})}{\text { areal unit sampling }(\mathrm{m} 2)}
$$

Ukuran estimasi secara visual dicatat berdasarkan total panjang (TL), yang lebih mudah untuk diestimasi, dibandingkan panjang fork (FL) untuk banyak spesies (Kulbicki et al., 2005).

\section{HASIL DAN PEMBAHASAN}

Persentase tutupan terumbu karang keras pada keempat stasiun yang berada di Pulau Kembar masuk dalam kategori sedang hingga baik. Menurut Yap dan Gomez (1988), tutupan karang keras hidup $(\mathrm{HC})$ pada stasiun 1 sisi bagian timur pulau Kembar masuk dalam kategori sedang dan merupakan stasiun yang paling rendah dibandingkan stasiun yang lain. Nilai patahan karang/Rubble (RB) dan Dead Coral (DC) di stasiun 1 merupakan paling tertinggi dibandingkan dengan stasiun lain di pulau Kembar.

Bentuk patahan karang (rubble) yang tersebar umumnya berasal dari karang ACB dan CB mati. Kondisi terumbu karang yang sedang dan nilai patahan karang yang tinggi di stasiun 1 pulau Kembar, diduga disebabkan oleh hempasan gelombang yang kuat, yang umum terjadi di perairan yang langsung terbuka dengan laut Jawa. Menurut Krishnan et al., (2013) karang dengan bentuk pertumbuhan bercabang lebih mudah patah dan menjadi pecahan karang bila terkena badai, hempasan ombak, atau arus yang kuat, hal ini sesuai dengan hasil nilai patahan karang yang sedang tinggi pada stasiun 1.

Stasiun 2 sisi bagian utara pulau Kembar memiliki nilai tutupan karang keras hidup (HC) masuk dalam kategori sedang hingga baik. Patahan karang atau Rubble (RB) adalah substrat abiotik yang banyak ditemukan pada stasiun ini. Unsur substrat lain yang dominan adalah DCA (Death Coral with Algae) dan DC (Death Coral) atau Karang Mati. Karakteristik perairan yang tidak jauh berbeda dengan stasiun 1 yaitu berhadapan langsung dengan laut terbuka, memperlihatkan hasil yang serupa, sehingga faktor alam sangat mempengaruhi tutupan karang keras hidup yang berada pada stasiun 2. DCA (Death Coral With Algae) juga banyak ditemukan di dasar perairan. Alga yang tumbuh pada karang mati dapat menjadi ancaman bagi karang karena menurut Castro dan Huber (2008), alga akan berkompetisi dengan karang untuk mendapat cahaya matahari.

Stasiun 3 dan 4 di pulau Kembar memiliki nilai tutupan karang keras hidup (HC) masuk dalam kategori baik. Patahan karang atau Rubble (RB) adalah substrat abiotik yang banyak ditemukan pada stasiun ini. Unsur substrat lain adalah DCA (Death Coral with Algae) dan DC 
(Death Coral) atau Karang Mati, memiliki nilai yang cukup rendah. Menurut Yuliani et al., (2016), patahan karang dapat disebabkan oleh ulah manusia yang menginjak karang dan pelepasan jangkar oleh nelayan di atas karang, hal ini berpengaruh dikarenakan letak stasiun yang berada dekat dengan pulau Parang yang menyebabkan tingginya aktifitas nelayan.

Kelimpahan ikan karang Famili Scaridae diperoleh berdasarkan perhitungan jumplah setiap spesies yang didapat dibagi dengan luas area pengamatan $\left(500 \mathrm{~m}^{2}\right)$. Nilai kelimpahan didapat dari hasil pengamatan visual sensus ikan dengan menghitung jumlah ikan dan berdasarkan kedalam setiap stasiun yaitu 3 meter dan 10 meter.cahaya yang cenderung tinggi dan menyebabkan proses fotosintesis berjalan dengan baik.

Kelimpahan ikan yang berbeda-beda pada tiap stasiun diduga disebabkan oleh perbedaan persentase penutupan karang hidup yang memberi pengaruh bagi kelangsungan kehidupan ikan karang, hal ini sesuai dengan pernyataan Nybakken (1992), bahwa ikan sebagai penyokong hubungan yang ada dalam ekosistem terumbu karang, sehingga rendahnya persentase tutupan karang keras hidup sangat berpengaruh terhadap kelimpahan ikan karang (Gambar 2).

Hasil tersebut sesuai dengan persentase tutupan karang keras hidup yang sedang pada stasiun 1, didapatkan hasil kelimpahan ikan karang famili scaridae yang rendah sebanyak 183 dan persentase tutupan karang keras hidup yang baik pada stasiun 4, didapatkan juga hasil kelimpahan ikan karang famili scaridae yang tinggi sebanyak 283 (Gambar 3). Tutupan karang keras berguna untuk tempat perlindungan ikan karang famili Scaridae, hal ini sesuai dengan pernyataaan Jones (1991) bahwa, peningkatan jumlah tempat perlindungan (HC) berdampak

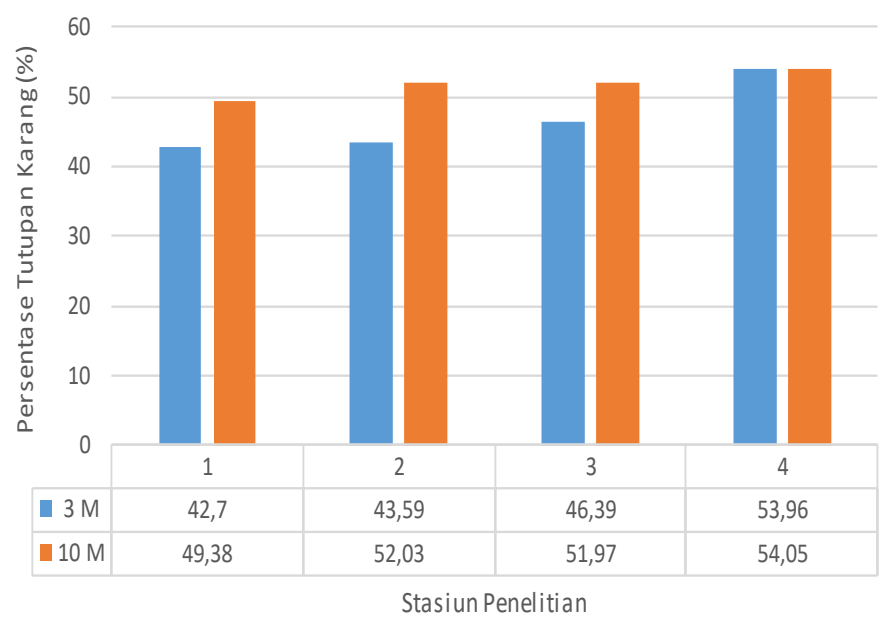

Gambar 2. Persentase Tutupan Karang Pada Setiap Stasiun di Pulau Kembar.

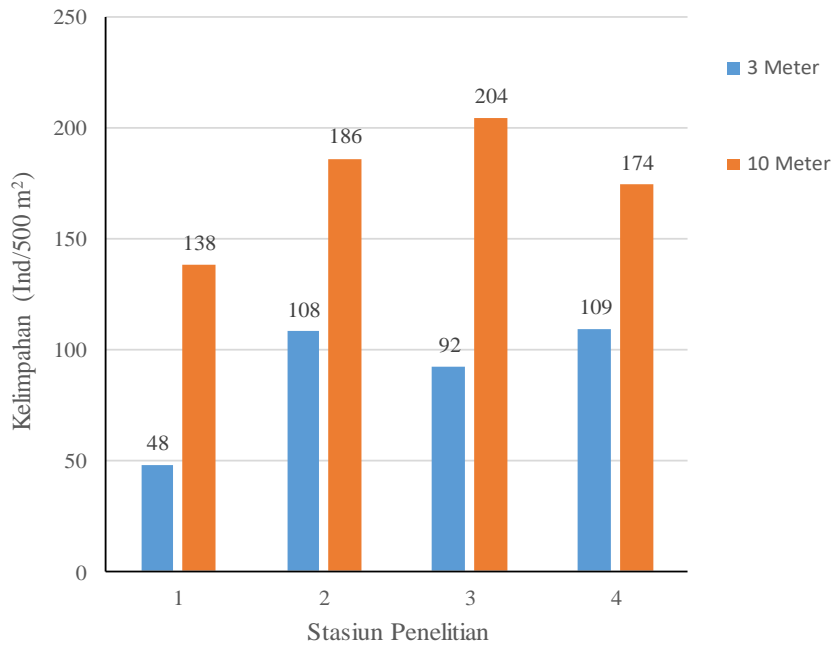

Gambar 3. Grafik Kelimpahan Ikan Karang Famili Scaridae di Pulau Kembar 
dalam peningkatan kelimpahan ikan yang secara spesifik menjadikan karang sebagai tempat persembunyian.

Kelimpahan ikan karang dari Famili Scaridae pada stasiun 2 dan 3 cukup tinggi dengan hasil tutupan karang keras yang cukup hingga baik. Kelimpahan ikan dari Famili Scaridae ini didukung oleh kebiasaan makan untuk membersihkan alga, sehingga membantu proses pertumbuhan karang keras hidup dan didukung oleh pernyataan Wibowo et al., (2016), bahwa Genus Chlorurus dalam trofik makanan merupakan ikan herbivora dengan tipe excavator yaitu menghilangkan substrat oleh gigitannya dan memainkan kunci dalam bioerosi sedangkan genus Scarus merupakan tipe scraper yaitu membuang alga, sedimen, dan bahan lainnya dengan memotong substrat dengan cermat.

Aspek lain yang mendukung tingginya kelimpahan ikan karang famili Scaridae adalah tingginya kelimpahan dari famili ikan herbivor yang lain yaitu Pomacentridae, dan Siganidae (tabel 3), hal ini sesuai dengan pernyataan Nybakken (1992), bahwa keberadaan ikan herbivora di dalam ekosistem terumbu karang memegang peranan penting dalam mempertahankan komunitas karang dalam berkompetisi dengan alga dan juga meningkatkan survival rekruitmen karang. Aspek tersebut dapat mendukung tingginya tutupan karang keras hidup yang berpengaruh terhadap kelimpahan ikan karang Famili Scaridae. Pernyataan tersebut sesuai dengan hasil yang didapat, dimana pada stasiun 3 kelimpakan ikan famili Scaridae, Pomacentridae, dan Siganidae cukup tinggi.

\section{Biomassa Ikan Karang Scaridae}

Biomassa ikan famili Scaridae diperoleh berdasarkan perhitungan kelimpahan (densitas) dikali dengan bobot individu dari setiap ikan. Nilai kelimpahan didapat dari hasil pengamatan visual sensus ikan dengan menghitung jumlah ikan, sementara nilai bobot didapat dari estimasi panjang ikan disetiap transek penelitian.

Berdasarakan hasil analisis data nilai biomassa ikan karang famili Scaridae di setiap stasiun dan kedalaman, nilai total berkisar dari 219,7 - 2491,7 kg/ha, sedangkan pada kedalaman 3 meter yang diamati nilai total biomassa selama penelitian adalah sebesar 219,7-1382,4 kg/ha, dengan stasiun paling tertinggi ada pada stasiun 3 bagian barat Pulau Kembar dan terendah berada pada stasiun 1 bagian timur Pulau Kembar (Gambar 4). Faktor yang mempengaruhi tingginya biomasa Famili Scaridae pada stasiun 3 penelitian adalah ukuran ikan yang cukup konstan yaitu berukuran 30-35 cm, yang sangat berpengaruh terhadap estimasi bobot ikan dari Famili Scaridae tersebut. Struktur ukuran dari populasi ikan adalah variabel yang sangat responsif terhadap perubahan dari tekanan perikanan atau interfensi pengelolaan (Micheli et al., 2004).

Tutupan karang keras hidup sangat berpengaruh terhadap kelangsungan hidup dan proses pekembangbiakan ikan Famili Scaridae. Hasil yang didapatkan tutupan karang keras hidup pada stasiun 3 lebih besar dari pada stasiun 1, hal ini berbanding lurus dengan total biomassa yang didapat dan didukung oleh pernyataan Wotton (1992) bahwa, Secara keseluruhan Famili Scaridae merupakan ikan yang hidup bergerombol di sekitar karang dan lamun pada perairan dangkal, dengan ukuran yang relatif kecil agar tubuh ikan dapat menyesuaikan diri untuk masuk kecelahcelah sempit karang, lubang, cekungan dan di antara daun-daun lamun. Adaptasi lain yaitu bentuk tubuhnya cenderung disesuaikan agar bisa berlindung di dasar perairan.

Nilai total pada kedalaman 10 meter yang diamati selama penelitian adalah sebesar 1869,8 $2491,7 \mathrm{~kg} / \mathrm{ha}$, dengan stasiun paling tertinggi ada pada stasiun 3 bagian barat Pulau Kembar dan terendah berada pada stasiun 1 bagian timur Pulau Kembar. Faktor yang mempengaruhi tingginya biomasa Famili Scaridae pada stasiun 3 diduga dikarenakan aktivitas di sekitar stasiun yang cukup minim dan letak pulau yang jauh dari aktifitas manusia. Aspek lain yang berpengaruh adalah tutupan karang keras hidup yang tinggi pada stasiun 3 yaitu berkisar 51,97\%, hal ini mendukung tingginya biomassa ikan karang dari Famili Scaridae di stasiun tersebut dikarenakan berperan penting dalam resilien karang dengan mengkonsumsi turf algae dimana dengan cara tersebut menghambat pertumbuhan alga yang berkompetisi ruang dengan karang (Wibowo et al., 2016). Tingginya jumlah individu ikan dari Famili Scaridae pada Stasiun 3 disebabkan oleh kebiasaannya yang suka bergerombol (schooling), Hal ini sesuai dengan pernyataann Setiawan et al., (2010) umumnya ikan karang yang memiliki biomassa dan kelimpahan tertinggi dijumpai dalam keadaan berkelompok (schooling). 


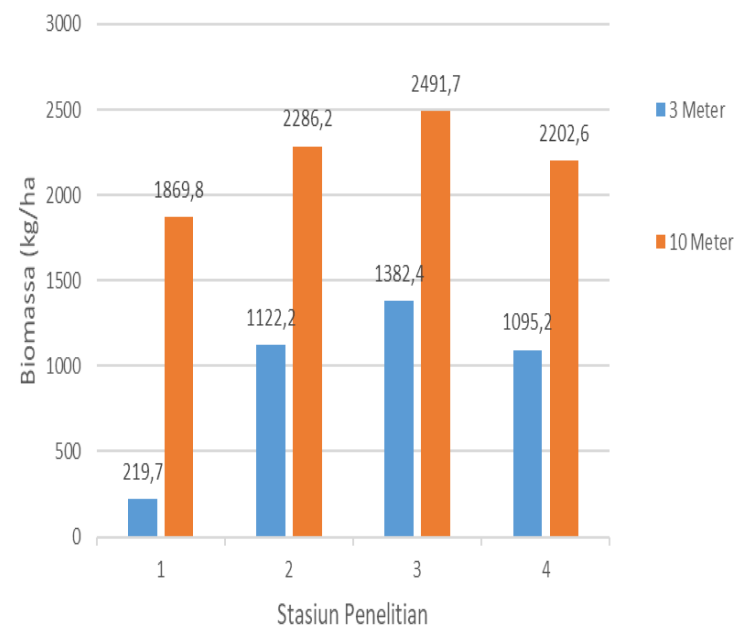

Gambar 4. Grafik Persentase Nilai Total Biomassa Famili Scaridae

Faktor yang mempengaruhi rendahnya nilai biomassa ikan karang seperti pada Stasiun 1 bagian timur Pulau Kembar adalah rendahnya persentase tutupan karang pada stasiun tersebut, hal ini sangat berpengaruh terhadap keberadaan dan kondisi biomassa ikan karang Famili Scaridae. Persentase yang sedang pada Stasiun 1 diduga disebabkan oleh hempasan gelombang yang kuat, yang umum terjadi di perairan yang langsung terbuka dengan laut Jawa. Menurut Krishnan et al., (2013) karang dengan bentuk pertumbuhan bercabang lebih mudah patah dan menjadi pecahan karang bila terkena badai, hempasan ombak, atau arus yang kuat, hal ini sesuai dengan hasil nilai patahan karang yang tinggi pada Stasiun 1.

\section{KESIMPULAN}

Berdasarkan hasil penelitian dapat disimpulkan yaitu nilai kelimpahan (ind $/ 500 \mathrm{~m}^{2}$ ) ikan karang Famili Scaridae berkisar antara 48 - 204 individu. Stasiun 1 bagian timur Pulau Kembar merupakan terendah dan stasiun 3 bagian barat Pulau Kembar paling tertinggi. Nilai biomassa (kg/ha) ikan karang Famili Scaridae berkisar antara 219,7 - 2491,7 kg/ha. Stasiun 1 bagian timur Pulau Kembar merupakan terendah dan stasiun 3 bagian barat Pulau Kembar paling tertinggi. Secara keseluruhan tutupan karang keras hidup sangat berpengaruh terhadap kelimpahan dan biomassa ikan karang dari Famili Scaridae.

\section{DAFTAR PUSTAKA}

Adrim, M. 2008. Aspek Biologi Ikan Kakatua (Suku Scaridae). Jurnal Oseana, 33(1):41-50.

Allen, G., Steen, R., Human, P., \& Deloach, N. 2003. Reef Fish Identification Tropical Pasific, New York Publication, Inc. Jacksonville, Forida, USA, $465 \mathrm{hlm}$.

Castro, P. \& Huber, M.E. 2008. Marine Biology, Seventh Edition. The McGraw Hill Companies. New York. $501 \mathrm{p}$.

English, S., Wilkinson, C. \& Baker, V. 1997. Survey Manual for Tropical Marine Resource. ASEANAustralia Marine Science Project Living Coastal Resource. Australia.

Gomez, E.D. \& Yap, H.T. 1998. Monitoring Reef Condition. In: Kenchington RA And Hudson BET (Eds). Coral Reef Management Hand Book. Unesco, Regional Office For Science And Technology For South East Asia. Jakarta

Hixon, M.A. 1991. Predation as a Process Structuring Coral Reef Fish Communities. Dalam: Sale PF (Eds). The Ecology of Fishes on Coral Reefs. Academic Press. San Diego.

Jones, G.P. 1991. Postrecruitmen Processes in the Ecology of Coral Reef Fish Population: A Multivactorial Perspective in Ecology of Fishes on Coral Reefs. Sale P.F.ed. New Hampshire. H 294-328 
Krishnan, P., George, G., Vikas, N., Immanuel, T., Goutham-Bharathi, M.P., Anand, A., Kumar, K.V. \& Kumar, S.S. 2013. Tropical storm off Myanmar coast sweeps reefs in Ritchie's Archipelago, Andaman. Environmental Monitoring and Assessment, 185(6):5327-5338. doi : 10.1007/s10661- 012-2948-7

Kulbicki, M., Guillemot, N. \& Amand, M. 2005. A General Approach to Length-Weight Relationship for New Caledonian Lagoon Fishes. Cybium, 29(3): 235-252.

Micheli, F., Halpern, B.S., Botsford, L.W., \& Warner, R.R. 2004. Trajectories and correlates of community change in no-take marine reserves. Ecological Applications, 14:1709-1723

Nybakken, J.W. 1993. Marine Biology: An Ecological Approach $3^{\text {rd }}$ ed. 475 p.

Sale, P.F. 1991. The Ecology of Fishes on Coral Reef. Academic Press, California, USA.

Setiawan, F. 2010. Panduan Lapangan Identifikasi Ikan Karang dan Invertebrata Laut. Wildlive Conservation Society. Manado. $350 \mathrm{hlm}$

Umardiono, A. 2011. Pengembangan Objek Wisata Taman Nasional Laut Kepulauan Karimunjawa. Jurnal Unair. 24(3):192-201

Wibowo, K., Abrar, M., \& Siringoringo, R.M. 2016. Status Trofik Ikan Karang dan Hubungan Ikan Herbivora dengan Rekrutmen Karang di Perairan Pulau Pari, Teluk Jakarta. Oseanologi dan Limnologi di Indonesia, 1(2):73-89. doi: 10.14203/oldi.2016.v1i2.85.

Wotton, R.J. 1992. Fish Ecology (tertiary level biology). Chapman and Hall, Inc. 29 West 35th street. New York. $187 \mathrm{p}$

Yuliani, W., Ali. S., \& Saputri, M. 2016. Pengelolaan Ekosistem Terumbu Karang Oleh Masyarakat di Kawasan Lhokseudu Kecamatan Leupung Kabupaten Aceh Besar. Jurnal IImiah Mahasiswa Pendidikan Biologi, 1(1):1-9.

Yusuf, M. 2013. Kondisi Terumbu Karang Dan Potensi Ikan Di Perairan Taman Nasional Karimunjawa, Kabupaten Jepara. Buletin Oseanografi Marina, 2(2):54-60. doi: 10.14710/bul oma.v2i2.6940 